\title{
KALIBRÁCIÓS MÓDSZER SZEMCSÉS HALMAZOK MIKROMECHANIKAI JELLEMZŐINEK MEGHATÁROZÁSÁHOZ
}

\section{CALIBRATION METHOD FOR DETERMINING MICROMECHANICAL PARAMETERS OF GRANULAR MATERIALS}

\author{
Safranyik Ferenc ${ }^{1}$, M. Csizmadia Béla ${ }^{2}$ \\ ${ }^{1}$ Szent István Egyetem, Gépészmérnöki Kar, Mechanika és Müszaki Ábrázolás Tan- \\ szék, 2100, Gödöllö, Páter Károly út 1, Telefon: 00362852200-1426, \\ safranyik.ferenc@hallgato.szie \\ ${ }^{2}$ Szent István Egyetem, Gépészmérnöki Kar, Mechanika és Müszaki Ábrázolás Tan- \\ szék, 2100, Gödöllö, Páter Károly út 1, Telefon: 00362852200-1423, csizma- \\ dia.bela@gek.szie.hu
}

\begin{abstract}
The practical usefulness of Discrete Element Method for modeling granular materials nowdays is very restricted. The problem is the determination of micromechanical parameters, so the calibration of the discrete model. Nowdays the calibrations is made by repeated attempts, for this reason it takes a long time, and highly difficult. For make easier the calibration the purpose of our work is a development of a calibration algorithm for Discrete element Method.
\end{abstract}

Keywords: granular materials, discrete element method, calibration, Yade.

\section{Összefoglalás}

A szemcsés halmazok leírására használt diszkrét elemes módszer gyakorlati alkalmazása jelenleg erősen korlátozott a számos, csak közvetve vagy sok esetben egyáltalán nem mérhető modellparaméter nehézkes meghatározása miatt. A paraméterek kalibrálását a legtöbb esetben próbálgatással végzik, emiatt a modell hitelesítése igen bonyolult és sok időt vesz igénybe, ezért célunk egy olyan algoritmus fejlesztése, amellyel a kalibráció egyszerüsíthető és gyorsítható.

Kulcsszavak: szemcsés halmazok, diszkrét elemes módszer, kalibráció, Yade.

\section{Bevezetés}

A szemcsés anyaghalmazok leírására napjainkban egyre szélesebb körben alkalmazzák az ún. diszkrét elemes módszert, amelyet a szemcsehalmazokkal kapcsolatos problémák numerikus vizsgálatára Cundall és Strack fejlesztett ki az 1970-es években [3]. Az ilyen diszkrét modell használata esetén a halmazt idealizált szemcsék (diszkrét elemek) együtteseként vizsgáljuk és ezek viselkedését, a rájuk vonatkozó kinetikai alaptételek alapján egy szimulációs ciklussal modellezzük [1]. A modellezés eredménye föként a diszkrét elemek közötti kölcsönhatások mechanikai paramétereitől, azaz az adott halmazra jellemző mikromechanikai paraméterektől (pl.: a 
szemcsék sűrüségétől, rugalmassági modulusától, Poisson-tényezőjétől, stb.) függ [1]. A módszer használatát a számos mikromechanikai paraméter meghatározása (a modell kalibrációja) nagymértékben megnehezíti, mivel, azok méréssel sok esetben csak közvetett módon, vagy egyáltalán nem határozhatóak meg [2]. Szintén nehézséget okoz, hogy a szemcsék kölcsönhatásait leíró matematikai modellekben szereplö állandók, sok esetben csupán közelítik a valódi mikromechanikai jellemzőket [3]. Emiatt elöfordulhat, hogy egy anyagra meghatározott, valamely jelenséget jól leíró paraméter együttes, ugyanezen anyagra vonatkozó másik probléma modellezésekor nem vezet jó eredményre.

Jelenleg nem létezik megfelelö hitelesítési eljárás, a legtöbb esetben próbálgatással határozzák meg a megfelelő mikromechanikai paramétereket, ezért a diszkrét elemes módszer gyakorlati alkalmazása egyelöre erősen korlátozott. Emiatt munkánk célja egy olyan kalibrációs eljárás fejlesztése, amellyel a megfelelő paraméterek meghatározása meggyorsítható és automatizálható.

\section{Nyíróvizsgálat}

Diszkrét modell használata esetén a teljes szemcsés halmaz (makro) viselkedését az egyes elemekre jellemző (mikro) paraméterek segítségével szimuláljuk [3]. Emiatt a mikromechanikai paraméterek hitelesítéséhez az adott halmazra jellemző tönkremeneteli határgörbét használjuk fel [5].

Ennek egyik meghatározási módszere a nyíróvizsgálat, amely során a halmazból vett mintát egy osztott kivitelü dobozba helyezzük és normál irányú, állandó terheléssel összenyomjuk (1. ábra). Az osztott kivitelü nyíródoboz felső része rögzített, alsó része pedig vízszintesen elmozdítható. A mérés során a nyírócella alsó, elmozdítható része a benne lévő anyaggal együtt vízszintesen elmozdul miközben a nyírási síkban erőmérő cellával mérjük a minta elnyírásához szükséges erőt, illetve a mozgó rész elmozdulását, így megkapjuk a tönkremenetelt okozó nyíróerö értékét [4].

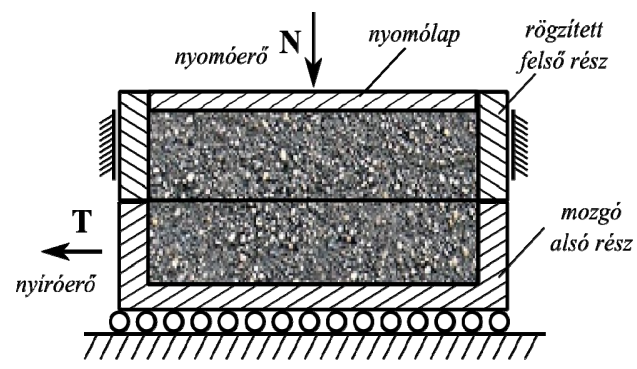

1. ábra: Nyirókészülék [4]

A nyíróvizsgálatot több normál terhelési értékkel elvégezve, majd a normál- és csúsztatófeszültségeket egy koordinátarendszerben ábrázolva megkapjuk az adott anyagra jellemző tönkremeneteli határgörbét (2. ábra) [4].

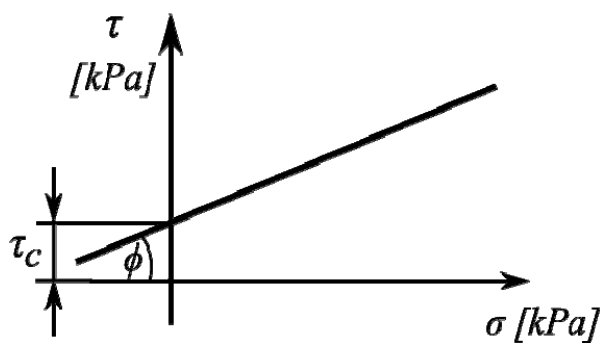

2. ábra: Tönkremeneteli határgörbe [4]

Az ideális ömlesztett anyagok tönkremeneteli határgörbéje origón átmenő egyenes, bizonyos szemcsés halmazok tönkremeneteli határgörbéje nemlineáris, és zérus normálfeszültség értékhez nem zérus csúsztatófeszültség tartozik, azonban a gyakorlatban, gyakran ilyen esetekben is lineáris közelítést használunk, mivel így is elegendően pontosan eredményt kapunk [4].

A tönkremeneteli határgörbe két, a teljes halmazra jellemző (makro) paraméterrel, a halmaz $\tau_{c}$, látszólagos kohéziójával és a halmaz $\phi$ belső súrlódási szögével írható 
le. Amennyiben a szimulációval kapott tönkremeneteli határgörbe megegyezik a méréssel meghatározottal, akkor a modellben beállított mikromechanikai paraméterek alkalmasak a halmaz viselkedésének leírására $[2,5]$.

\section{A diszkrét elemes modell}

A kalibrációs módszer fejlesztéséhez egy nyílt forráskódú diszkrét elemes szoftvert, a Yade-t használtuk. A szoftver legföbb elönye, - amellett, hogy ingyenesen használható - hogy a szimulációkat Python [7] nyelven írt programokkal irányíthatjuk [6]. Ez nagyfokú szabadságot eredményez, mivel tetszőleges geometria és tetszöleges (akár szabályozott) technológiai folyamatok modellezését is lehetővé teszi.

Az automatikus kalibráló algoritmus fejlesztéséhez elsőként a klasszikus Jenikeféle nyírókészülék [4] módosított (négyzet keresztmetszetü nyíródoboz) diszkrét elemes modelljét hoztuk létre (3. ábra).

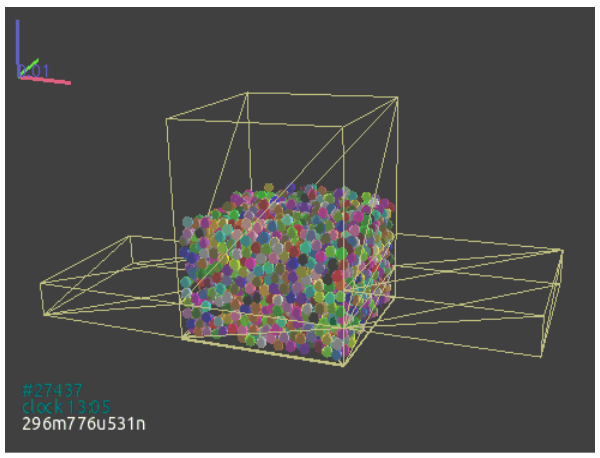

3. ábra: A nyíródoboz diszkrét elemes modellje

A szimulációk során gömb alakú szemcséket, a kölcsönhatások leírására pedig a Hertz-Mindlin-féle kohéziós kapcsolati modellt alkalmaztuk [6]. A szoftver nyújtotta széleskörü felhasználói szabadság lehetővé tette, hogy a tényleges nyíróvizsgálat folyamatát (állandó normálterhelés melletti nyírást) modellezzük (4. ábra).

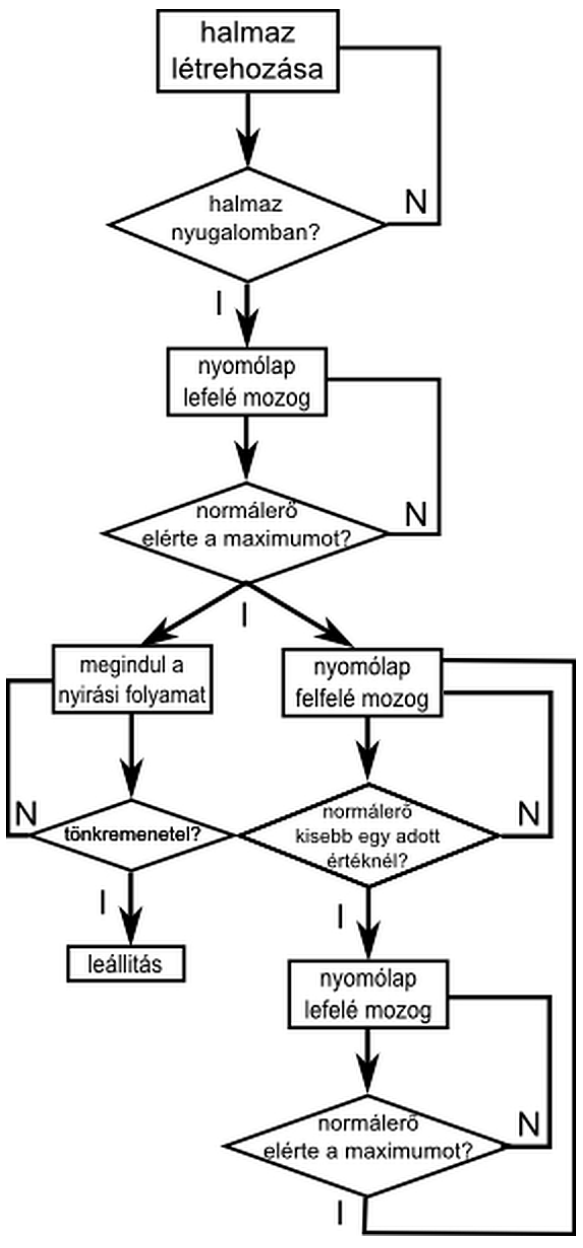

4. ábra: A nyíróvizsgálat szimulációs modelljének felépitése

A legtöbb diszkrét elemes modell a szemcsék kölcsönhatását rugókból és csillapításokból álló lengörendszerként írja le $[3,5,6]$, ezért minden esetben el kell érni a rezgések lecsillapodását, annak érdekében, hogy kvázi statikus állapotban lévő halmazt vizsgálhassunk. Esetünkben addig, míg a halmaz összes mozgási energiája közel zérus nem lesz, egyik test sem végez mozgást (4. ábra). Mikor a halmaz elérte a kvázi statikus állapotot, megindul a nyírási folyamat, miközben a nyomólap mozgását a normálterhelés függvényében szabályoz- 
zuk, így biztosítva a nyírási folyamat alatt, az állandó nagyságú normálterhelést. Így a valósághoz teljesen hasonlóan modellezhető a nyíróvizsgálat, amelyre eddig nem volt lehetőség, mivel a legtöbb szoftverben az egyes elemek mozgása csak elmozdulásra szabályozható, a kölcsönhatásokra jellemző adatok (pl.: a keletkező erők) csakis a számítások elvégzése után nyerhetők ki, a szimulációkban közvetlenül nem használhatóak fel (4. ábra).

\subsection{Kalibrációs algoritmus}

A fent bemutatott szimulációt felhasználva létrehoztunk egy kalibrációs algoritmust, amely segítségével tetszőleges számú nyíróvizsgálatot végezhetünk el, külső beavatkozás nélkül. Az algoritmus tetszőleges számú, elöre definiált normál terhelés értékkel szimulálja a nyíróvizsgálatot, és az egyes szimulációkkal kapott normál-, és csúsztatófeszültség értékeket elmenti, közös koordináta rendszerben ábrázolja. majd lineáris regressziót végez. Ez alapján megkapjuk az adott halmazra jellemző két legfontosabb paramétert, a látszólagos kohéziót és a belső súrlódási szöget. (5. ábra).

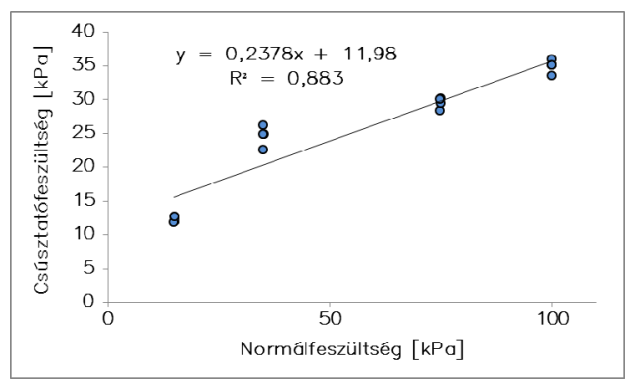

5. ábra: Az algoritmus 16 nyíróvizsgálat szimulációjával kapott tönkremeneteli határgörbe

Eddig ilyen automatizált módszer nem állt rendelkezésre, a tönkremeneteli határgörbe valamennyi pontjának kiszámításához egyesével kellett beállítanunk és futtatnunk a szimulációkat (amelyek számítási ideje akár több nap is lehet), majd kiértékelnünk őket.

\section{Következtetések}

Szimulációs algoritmusunk segítségével a mikromechanikai paraméterek bármilyen kombinációjával lehetőségünk nyílik - az eddigieknél sokkal gyorsabban és egyszerübben - a halmaz makro jellemzőinek meghatározására. E révén a jelenleg használatos, „próbálgatásos” kalibrációs eljárás egyszerüsödik, az egyes mikromechanikai paraméterek makro jellemzőkre gyakorolt hatása nagyságrendekkel kevesebb idő alatt megállapítható.

További célunk az algoritmus továbbfejlesztése, az egyes paraméterek pontos hatásának, valamint mérések alapján ismert referencia adatok ismeretében teljesen automatikusan müködő kalibráló algoritmus kidolgozása.

\section{Szakirodalmi hivatkozások}

[1] Bagi K.: A diszkrét elemek módszere, BME Tartószerkezetek Mechanikája Tanszék, 2007.

[2] Coetzee C.J., Els D.N.J.: Calibration of discrete element parameters and the modelling of silo discharge and bucket filling, Computers and electronics in agriculture, 65, 2009, 198-212. oldal

[3] Cundall P.A., Strack O.D.L.: A discrete numerical model for granular assemblies, Geotechnique, 29, 1979, 47-65. oldal

[4] Jenike A. W.: Storage and Flow of solids, Bulletin No. 123, Utah Engineering Experiment Station, University of Utah, Salt Lake City, 1964.

[5] Keppler I., Kocsis L., Oldal I., Farkas I., Csatár A.: Grain velocity distribution in a mixed flow dryer, Advanced Powder Technology, 23, 2012, 824-832. oldal

[6] Šmilauer V., Catalano E., Chareyre B., Dorofeenko S., Duriez J., Gladky A., Kozicki J., Modenese C., Scholtès L..: Yade Documentation (V. Šmilauer, ed.), The Yade Project, 1st ed., 2010, http://yadedem.org/doc/

[7] Swinnen G.: Tanuljunk meg programozni Python nyelven, 2005, http://learnpython.openproject.hu 